DOI: $10.36910 / 6775-2524-0560-2020-40-15$

УДК: 681.2

Чайковський Сергій Юрійович, старший науковий співробітник

https://orcid.org/0000-0002-2891-0845

Випробувальна лабораторія Українського науково-дослідного інституту спеціальної техніки та судових експертиз Служби безпеки України

\title{
ПЕРСПЕКТИВНІ НАПРЯМКИ ЗАСТОСУВАННЯ ЗАСОБІВ ВИМІРЮВАЛЬНОЇ ТЕХНІКИ ДЛЯ ПРОВЕДЕННЯ ВИПРОБУВАНЬ ПРОДУКЦІЇ В АКРЕДИТОВАНИХ ЛАБОРАТОРІЯХ УКРАЇНИ.
}

\begin{abstract}
Чайковський С. Ю. Перспективні напрямки застосування засобів вимірювальної техніки для проведення випробувань продукції в акредитованих лабораторіях України. У статті проведено аналітичний огляд стану та можливостей акредитованих лабораторій для випробувань в Україні. Розглянуто тенденції розвитку засобів вимірювальної техніки. Визначено чинники, які впливають на розвиток напрямків застосування засобів вимірювальної техніки для проведення випробувань продукції в акредитованих лабораторіях України. Сформульовано основні перспективні напрямки застосування засобів вимірювальної техніки для проведення випробувань продукції у акредитованих лабораторіях України.

Ключові слова:засоби вимірювальної техніки, акредитована лабораторія, випробування, випробувальне обладнання, продукція, перспективні напрямки.
\end{abstract}

Чайковский С. Ю. Перспективные направления применения средств измерительной техники для проведения испытаний продукции в аккредитованных лабораториях Украины. В статье проведен аналитический обзор состояния и возможностей аккредитованных лабораторий для испытаний в Украине. Рассмотрены тенденции развития средств измерительной техники. Определены факторы, влияющие на развитие направлений применения средств измерительной техники для проведения испытаний продукции в аккредитованных лабораториях Украины. Сформулированы основные перспективные направления применения средств измерительной техники для проведения испытаний продукции в аккредитованных лабораториях Украины.

Ключевые слова: средства измерительной техники, аккредитованная лаборатория, испытания, испытательное оборудование, продукция, перспективные направления.

Tchaikovsky Sergiy. Promising directions of application of measuring equipment for product testing in accredited laboratories of Ukraine. The article provides an analytical review of the state and capabilities of accredited laboratories for testing in Ukraine. Trends in the development of measuring equipment are considered. The factors influencing the development of directions of application of measuring equipment for product testing in accredited laboratories of Ukraine are determined. The main perspective directions of application of measuring equipment for product testing in accredited laboratories of Ukraine are formulated.

Key words: measuring equipment, accredited laboratory, tests, test equipment, products, perspective directions.

Постановка проблеми.Сучасний стан світового ринку вимагає вирішення проблеми взаємного визнання результатів оцінювання відповідності продукції. Вступ України до Світової організації торгівлі, підписання Асоціації з СС передбачають виконання низки вимог, зокрема приведення у відповідність національної системи технічного регулювання до європейської $[1,2]$. Адаптація національної системи технічного регулювання України, в сфері технічного регулювання, до міжнародних і європейських стандартів $є$ одним з головних напрямків інтеграції в світові та європейські структури [3-7].

Аналіз останніх досліджень і публікацій.Питанням адаптації національної системи технічного регулювання, в сфері технічного регулювання, до міжнародних і європейських стандартів присвячено велику кількість публікацій. Найзначнішими серед них $є$ роботи Б. Стадника, Є. Володарського, М.Микийчука, Л.Кошевої, В. Кравчука, О. Мельниченко, О. Малецької,А.Зенкіна, С. Сєдова. Велика кількість робіт, найпомітнішими з яких $є$ [1, 8-11], опублікована і за кордоном. Однак, незважаючи на велику кількість праць, присвячених проблемам технічного регулювання, недостатньо розглянуто питання щодо визначення перспективних напрямків застосування засобів вимірювальної техніки (ЗВТ) для проведення випробувань продукції в акредитованих лабораторіях України.

Метою дослідженняє визначення основних перспективних напрямків застосування ЗВТ для проведення випробувань продукції у акредитованих лабораторіях України. Реалізація поставленої мети передбачає виконання таких завдань дослідження:аналітичний огляд стану та можливостей акредитованих лабораторій для випробувань в Україні; встановлення тенденцій розвитку ЗВТ, що використовуються для випробувань продукції в акредитованих лабораторіях в Україні; визначення чинників, які впливають на розвиток напрямків застосування ЗВТ для проведення випробувань продукції в акредитованих лабораторіях в Україні.

Виклад основного матеріалу дослідження.Автор не претендує на повне викладення всіх перспективних напрямків застосування ЗВТ для проведення випробувань продукції у акредитованих лабораторіях України, тому у статтізроблена лише спроба систематизувати та визначити основні з них. 
Коротко зупинимось на термінах та визначеннях, що використовуються у статті. Випробування продукції - це один із методів іï технічного контролю. Під випробуванням розуміється визначення однієї чи більше характеристик об'єкта оцінки відповідності згідно з процедурою[1, 2].Випробування дає можливість об'єктивно оцінити технічний рівень і якість продукції на всіх стадіях іiі життєвого циклу - починаючи з розроблення і поставлення продукції на виробництво і закінчуючи експлуатацією [12]. А продукція - це результат процесу $[1,2]$.

Стандарт ISO 9000: 2000 [13] встановлює 4 загальні категорії продукції: послуги (наприклад, транспортування); інтелектуальна продукція (наприклад, програмне забезпечення, технологія виробництва тощо); технічні засоби (наприклад, холодильна установка, персональний комп'ютер тощо); матеріали, що переробляються (наприклад, мастило).

В Україні фахівці розрізняють поняття “випробувальне обладнання” та “засоби вимірювальної техніки”. Випробувальне обладнання застосовують для відтворення умов випробувань, тобто це технічні засоби, які у певний спосіб впливають на об'єкт досліджень упродовж необхідного часу. ЗВТ застосовують для проведення вимірювань, тобто за їх допомогою реалізують процес експериментального визначення одного або декількох значень величини, що можуть бути обгрунтовано приписані цій величині [14].

Аналітичний огляд стану та можливостей акредитованих лабораторій для випробувань в Україні.В Україні випробуванняпродукції проводятьсяв акредитованих лабораторіях для визначення відповідності характеристик іiі властивостей національним, європейським чи міжнародним нормативним документам. Під час випробуваньвстановлюються показники якості продукції, в тому числі ії відповідності вимогам безпеки і охорони навколишнього середовища [15]. Загальна кількість акредитованих в Україні на 01.09.2020 року - 426 (не враховано дані по АР Крим, по Донецькій та Луганській областям) [15]. Розподіл акредитованих лабораторій для проведення випробувань в областях України наведено на рисунку 1. Із рисунку 1 видно, що найбільша чисельність акредитованих лабораторій знаходиться у Київській області - 111, у Дніпровській області - 42, у Харківській області - 37 та у Одеській області - 31, а найменша чисельність акредитованих лабораторій знаходиться у Закарпатській області - 4 і у Чернівецькій області - 2.

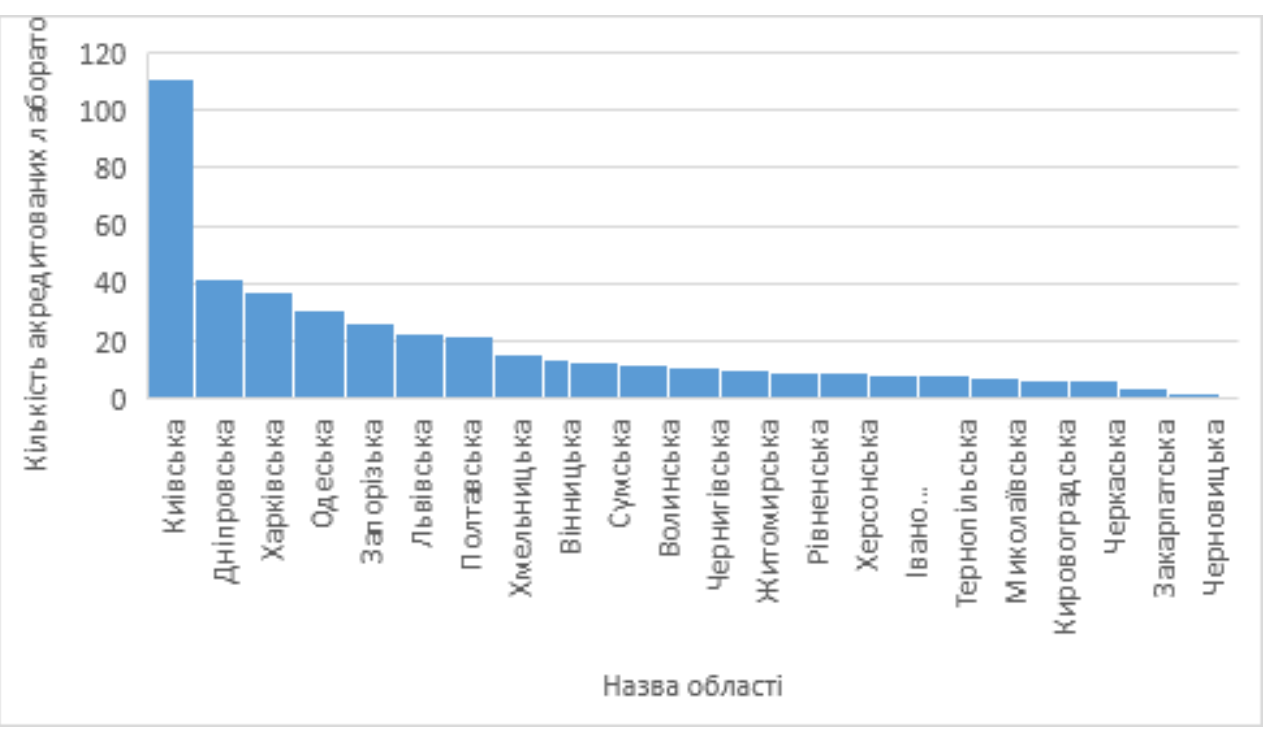

Рис. 1. Розподіл акредитованих лабораторій для проведення випробувань в областях України

На сьогодні в Україні акредитовані лабораторії проводять випробування не менш як за 16 найменуваннями продукції (наприклад, будівельні матеріали та конструкції, продукти харчування, електрообладнання тощо) та за 17 основними категоріями випробувань (наприклад, хімічні, механічні, електричні, мікробіологічні тощо). В таблиці 1 наведено ранжування видів продукції залежно від частоти їх використання під час випробувань в акредитованих лабораторіях України. 3 цієї таблиці видно, що найбільш затребуваною продукцією є будівельні матеріали та конструкції, продукти харчування, електрообладнання, транспорті засоби, машини, верстати і обладнання.І відповідно найменш затребуваною продукцією для випробувань $є$ вироби для залізничного транспорту.

До будівельних матеріалів, що підпадають під випробування належать: пісок, щебінь та гравій, шпали, пиломатеріали, вироби паркетні, блоки віконні та дверні, суміші будівельні системи утеплення, 
пластик, вироби керамічні в тому числі плитки керамічні і черепиця керамічна, вапно будівельне, блоки бетонні, листи гіпсокартонні, оснастка монтажна тощо).

До засобів зв'язку і радіоустаткування належать: випробування кінцевого обладнання електрозв'язку апаратів телефонних всіх класів і приставок до них; таксофонів для міжнародного, міжміського та місцевого зв'язку; АТС і концентраторів; модемів, факсмодемів, обладнання ущільнення абонентських ліній і мультікомплексорів абонентських; терміналів телеграфних, пристроїв для взаємодії 3 мережами АТ-50, ТЕЛЕКС i ТГ-ОП; апаратів факсиміле i пристроїв багатофункціональних з факсимільним режимом роботи; іншого кінцевого обладнання електрозв'язку.

До продуктів харчування як об'єкта випробувань належать зразки продукції тваринного, рослинного і біотехнологічного походження.

Таблиця 1. Розподіл та номенклатура продукції, що підлягає випробуванням в Україні

\begin{tabular}{|c|l|c|}
\hline \multicolumn{1}{|c|}{ № 3/п } & \multicolumn{1}{|c|}{ Назва продукції } & $\begin{array}{c}\text { Кількість лабораторій в } \\
\text { яких ця продукція } \\
\text { випробовується }\end{array}$ \\
\hline 1 & Будівельні матеріали та конструкції & 130 \\
\hline 2 & Продукти харчування & 122 \\
\hline 3 & Електрообладнання & 77 \\
\hline 4 & Транспорті засоби & 69 \\
\hline 5 & Машини, верстати, обладнання & 68 \\
\hline 6 & Побутова хімія та косметика & 47 \\
\hline 7 & Продукти нафтоперероблення & 45 \\
\hline 8 & Засоби захисту & 40 \\
\hline 9 & Посуд & 31 \\
\hline 10 & Засоби зв'язку і радіоустаткування & 24 \\
\hline 11 & Кабельно-провідникова продукція & 22 \\
\hline 12 & Іграшки & 21 \\
\hline 13 & Медична техніка & 18 \\
\hline 14 & Світлотехніка & 18 \\
\hline 15 & Сільськогосподарська техніка & 18 \\
\hline 16 & Залізничні вироби & 14 \\
\hline
\end{tabular}

В таблиці 2 наведено ранжування категорій за якими проводяться випробування в Україні залежно від частоти їх використання. 3 таблиці 2 видно, що найбільш затребуваними категоріями випробувань продукції є хімічні, механічні, електричні, мікробіологічні, радіологічні, бактеріологічні та динамічні. I відповідно найменш затребуваними категоріями випробувань продукції є радіаційні випробування.

Таблиця 2. Розподіл та номенклатура категорій, за якими проводяться випробування в Україні

\begin{tabular}{|c|l|c|}
\hline \multicolumn{1}{|c|}{ Назва категорії } & $\begin{array}{c}\text { Кількість лабораторій в } \\
\text { яких за цими категоріями } \\
\text { проводяться випробування }\end{array}$ \\
\hline 1 & Хімічні & 278 \\
\hline 2 & Механічні & 271 \\
\hline 3 & Електричні & 134 \\
\hline 4 & Мікробіологічні & 128 \\
\hline 5 & Радіологічні & 121 \\
\hline 6 & Бактеріологічні & 117 \\
\hline 7 & Динамічні & 112 \\
\hline 8 & Біологічні & 85 \\
\hline 9 & Електромагнітні & 79 \\
\hline 10 & Кліматичні & 76 \\
\hline 11 & Вібраційні & 54 \\
\hline 12 & Ступінь захисту ІР & 53 \\
\hline 13 & Шумові & 41 \\
\hline 14 & Металографічні & 30 \\
\hline 15 & Пожежні & 19 \\
\hline 16 & Магнітні & 16 \\
\hline 17 & Радіаційні & 9 \\
\hline
\end{tabular}


В акредитованих лабораторіях під час випробувань використовуються лише апробовані та забезпечені відповідним випробувальним обладнанням та ЗВТ методи випробувань. Так, наприклад, для випробування продуктів харчування, посуду та іграшок використовуються [16]:

- хроматографічні методи (газова, тонкошарова, високоефективна рідинна хроматографія);

- методи атомної абсорбції (полум'яна, електротермічна, емісійна);

- методи капілярного електрофорезу;

- фізико-хімічні методи (титрометричний, потенціометричний, рефрактометричний, фотоелектроколориметричний та гравіметричний методи);

- методи полімеразної ланцюгової реакції в реальному часі для визначення ГМО;

- методи контролю алкогольних напоїв за фізико-хімічними показниками та на справжність;

- мікробіологічні методи досліджень.

На рисунках 2-5 наведено результати досліджень видів продукції, що підлягають випробуванням та категорії за якими проводяться випробування в акредитованих лабораторіях Київської та Дніпровської областей (це області 3 найбільшою кількістю акредитованих для випробувань лабораторій). Ці області України, як видно з рисунку 1, мають найбільшу кількість атестованих випробувальних лабораторій.

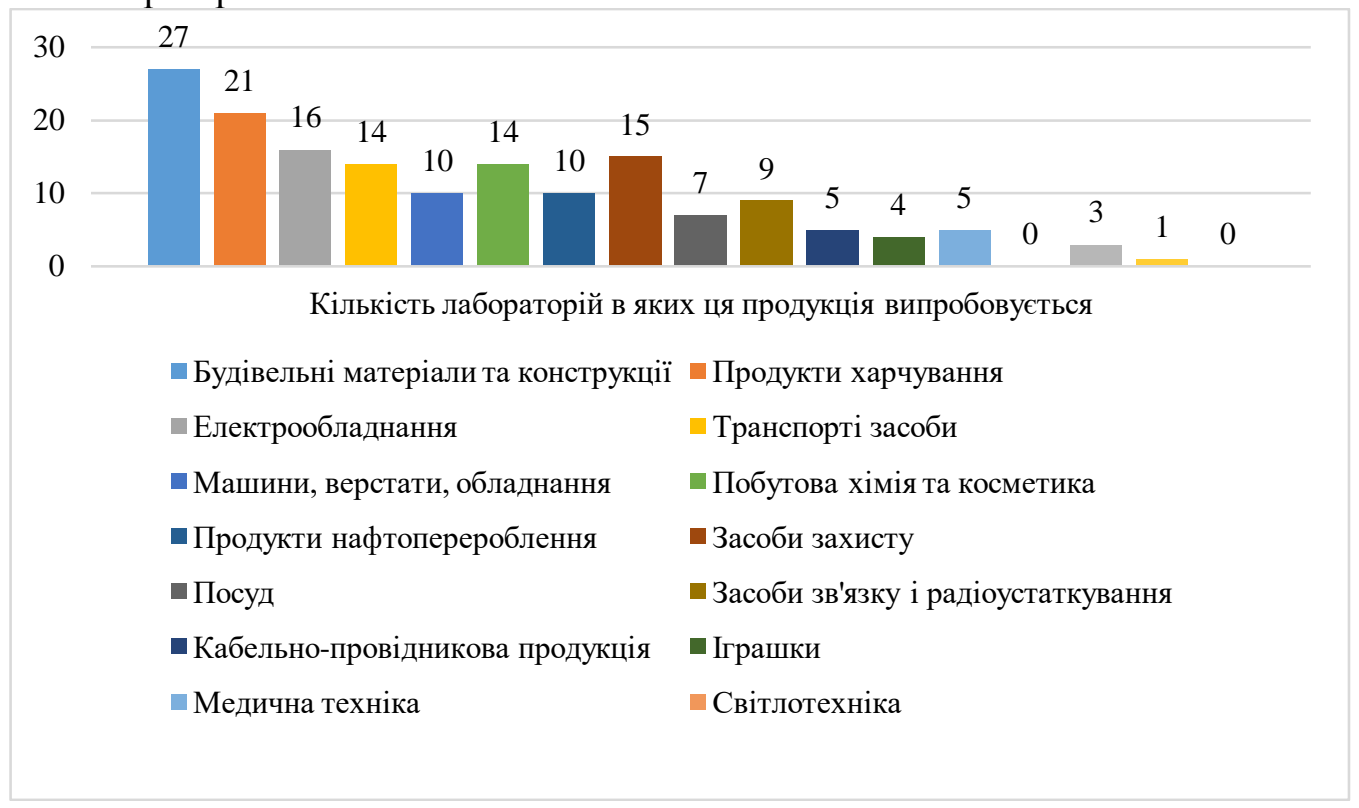

Рис. 2. Перелік продукції, що підлягає випробуванням в акредитованих лабораторіях в Київській області

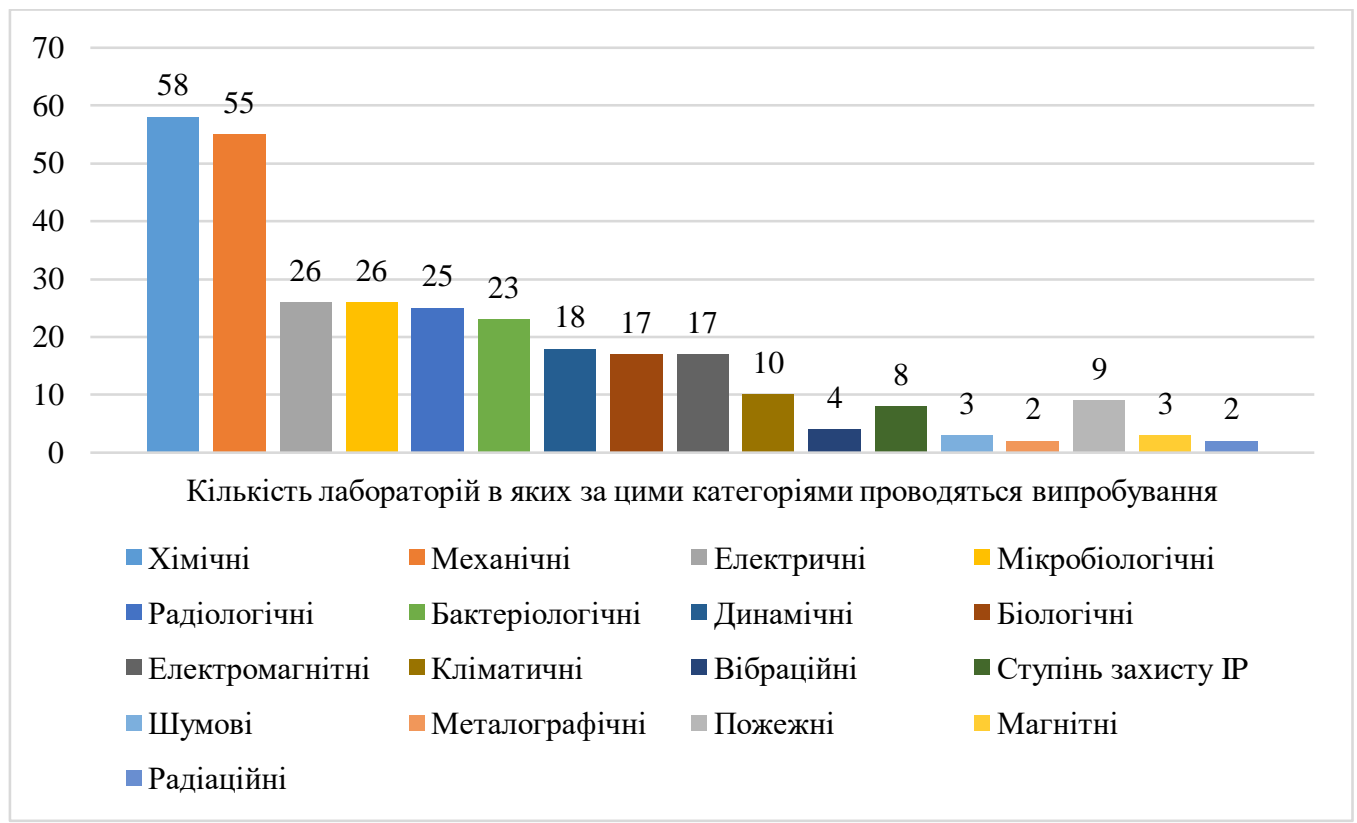

Рис. 3. Перелік категорій за якими проводять випробування в 
акредитованих лабораторіях в Київській області

3 рисунків 2 та 4 можна бачити, що в акредитованих лабораторіях Київської та Дніпровської областей більший відсоток випробувальної продукції займають будівельні матеріали та конструкції, продукти харчування і електрообладнання. Слід відзначити, що для Київської області показники кількості лабораторій, в яких ця продукція випробовується, перевищує практично в 2 рази ніж в Дніпровській області. А відповідно, найменше випробуванням в цих областях підлягають медична та сільськогосподарська техніка.

Рисунки 3 та 5 ілюструють, що найбільш популярними категоріями за якими проводять випробування в акредитованих лабораторіях у Київській та Дніпровській областях $є$ хімічні та механічні, причому показники кількості лабораторій, в яких за цими категоріями проводяться випробування для Київської області більш ніж в 2 рази перевищують ніж в Дніпровській області. Найменш популярними категоріями за якими проводять випробування в акредитованих лабораторіях у Київській області це радіаційні, а у Дніпровській - пожежні, магнітні та радіаційні.

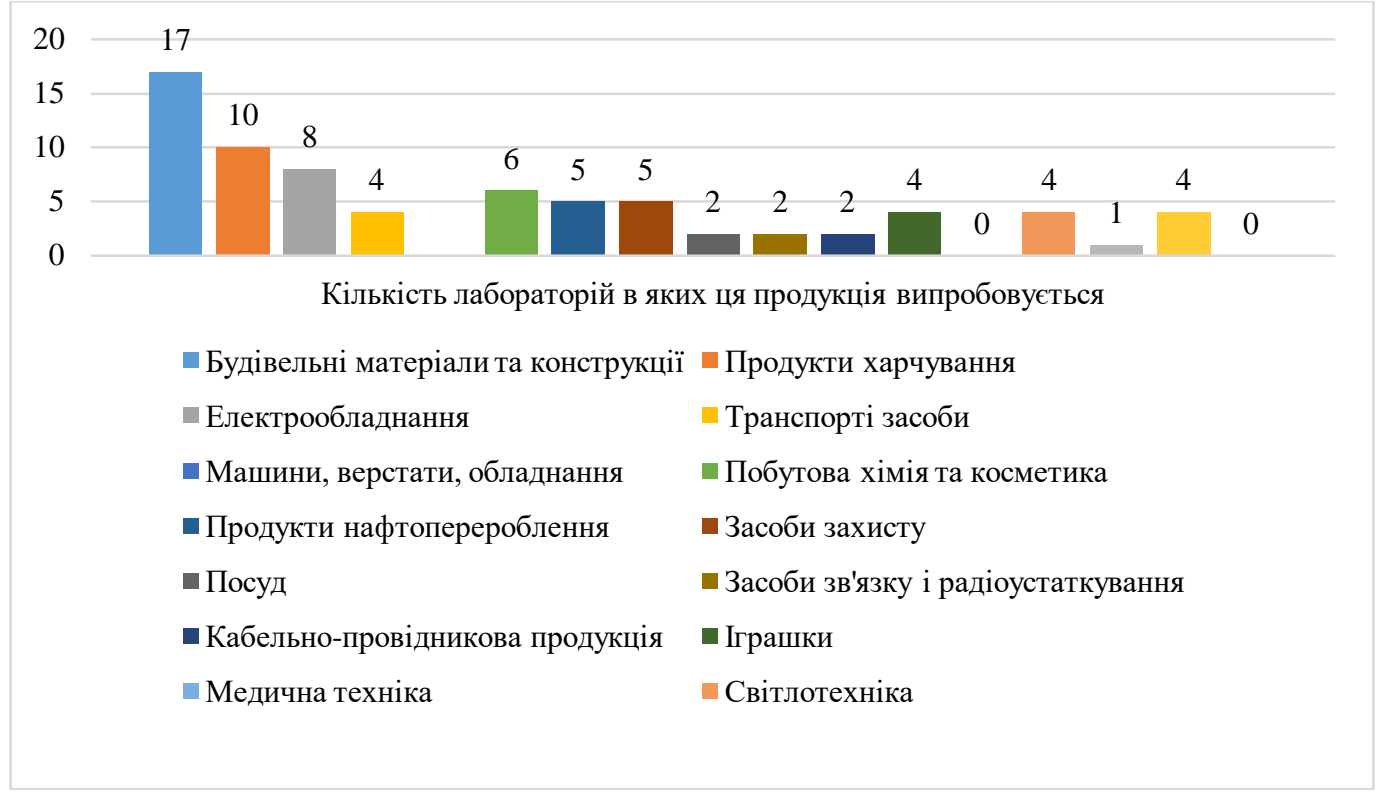

Рис. 4. Перелік продукції, що підлягає випробуванням в акредитованих лабораторіях в Дніпровській області

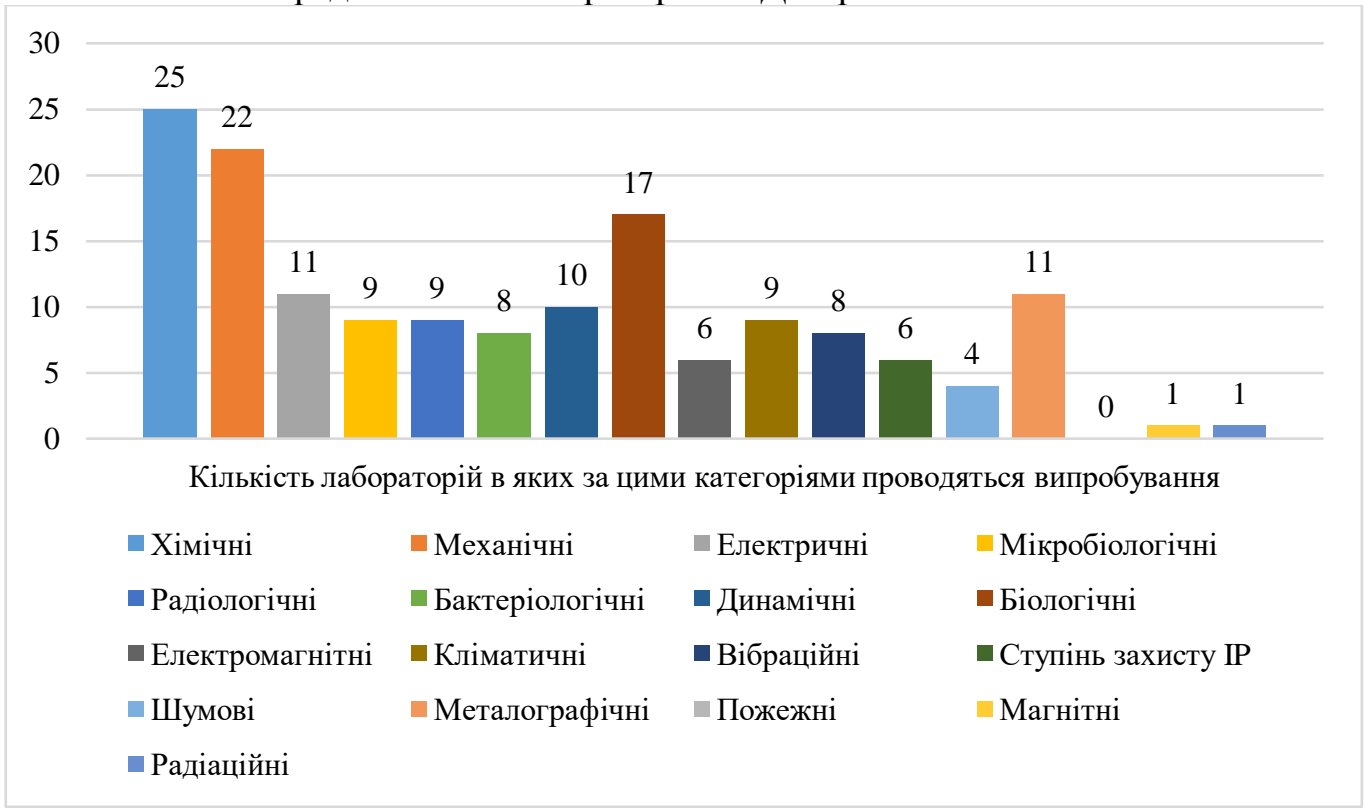

Рис. 5. Перелік категорій за якими проводять випробування в акредитованих лабораторіях в Дніпровській області 
Тендениії розвитку ЗВТ.Визначимо загальні тенденції розвитку ЗВТ (i, зокрема, для випробувань в акредитованих лабораторіях України):

- підвищення темпів виробництва і продажу цифрових ЗВТ в Україні й інших провідних країнах. 3 певним часом цифрові ЗВТ повністю замінять аналогові ЗВТ, тому що на відміну від аналогових, цифрові ЗВТ мають стрімку перспективу розвитку [17];

- набуття універсальності ЗВТ за рахунок широкого застосування великої кількості вимірювальних сигналів, що отримані на основі використання методів цифрової обробки. Використання такого підходу дозволяє значно розширити клас розв'язуваних задач, в основному, за рахунок розроблення програмного забезпечення без істотного апаратурного ускладнення 3ВТ[18];

- суттєве покращенняексплуатаційних та технічних характеристик ЗВТ. Пріоритетний розвиток i постійне зростання обсягів продаж ЗВТ, в першу чергу,пов'язані з істотним поліпшенням їх технічних, особливо метрологічнихі експлуатаційних характеристик [17];

- удосконалення і стандартизація інтерфейсу ЗВТ. Можливості ЗВТ істотно розширює наявність стандартного інтерфейсу, що дозволяє об'єднувати їх у вимірювальні та інші системи, наприклад, досить поширені системи збору й обробки даних. Інтерфейсні плати випускаються сумісними з певною мовою системного програмного забезпечення [19];

- інтелектуалізація 3ВТ - є однією з пріоритетних тенденцій у закордонному приладобудуванні, тому що на інтелектуалізації базуються не тільки підвищення універсальності ЗВТ, стандартизація інтерфейсу ЗВТ але й поліпшення їх технічних і експлуатаційних характеристик. Вона гармонійно об'єднує попередні тенденції, але потребує суттєвих витрат. ÏÏ сутність полягає в тому, що множина різноманітних за функціями ЗВТ замінюється одним універсальним, який об'єднує можливості середнього комп'ютера, переваги цифрових методів перетворення й обробки інформації, наочність графічних форм відображення результатів;

- розроблення спеціалізованого програмного забезпечення інтелектуальних ЗВТ для розширення їх функціональних можливостей, у тому числі для підвищення інтелектуалізації розв'язуваних задач при одночасному спрощенні їх експлуатації, i для зменшення середньої вартості виконання однієї вимірювальної задачі.

Чинники, які впливають на розвиток напрямків застосування ЗВТ для проведення випробувань продукції в акредитованих лабораторіях України.3 метою визначення основних напрямків застосування ЗВТ в акредитованих лабораторіях під час випробувань продукції необхідно визначити чинники, що впливають на розвиток зазначених вище напрямків. До основних з них, слід віднести такі:

- тенденції розвитку ЗВТ в Україні та у провідних економічно розвинутих країнах світу;

- пріоритетні напрями розвитку технічного регулювання в Україні;

- стан процесу адаптації національного законодавства в частині технічних регламентів та оцінки відповідності із законодавством Свропейського союзу;

- стан розроблення та прийняття технічних регламентів і процедур оцінки відповідності;

-стан Міжнародного співробітництваУкраїни у сфері технічного регулювання.

Якщо розглядати вплив зазначених чинників на розвиток напрямків застосування ЗВТ для випробування продукції, то слід відмітити його неоднозначність та суперечливість- деякі 3 них впливають напряму, а деякі опосередковано. Але це питання потребує окремих досліджень і не буде розглядатися в цій статті.

Основні перспективні напрямки застосування ЗВТ для проведення випробувань продукиї в акредитованих лабораторіях Украӥни.На основі наведених вище аналітичного огляду, тенденцій розвитку ЗВТ та чинників впливу можна стверджувати, що основнимиперспективними напрямками застосування ЗВТ для проведення випробувань продукції в акредитованих лабораторіях України є:

- використання ЗВТ під час сертифікації насіння і садивного матеріалу;

- використання 3ВТ під час сертифікації органічного виробництва та обігу органічної продукції;

- використання ЗВТ під час сертифікації суб'єктів та об'єктів авіаційної діяльності;

- використання ЗВТ під час державної експертизи у сферах криптографічного захисту інформації;

- використання ЗВТ під час затвердження конструкції колісних транспортних засобів, їх предметів обладнання і частин;

- використання ЗВТ під час оцінки відповідності певних видів послуг.

Висновки та перспективи подальших досліджень.Таким чином, у статті вирішено поставлені такі завдання: проведено аналітичний огляд стану та можливостей акредитованих лабораторій для випробувань в Україні; встановлено тенденції розвитку ЗВТ; визначеночинники, які впливають на розвиток напрямків застосування ЗВТ для проведення випробувань продукції в акредитованих 
лабораторіях в Україні. Це дозволило визначити основні перспективні напрямки застосування ЗВТ для проведення випробувань продукції у акредитованих лабораторіях України. Подальшим актуальним напрямком досліджень є розроблення методик оцінювання рівня якості проведення окремих випробувань.

\section{Список бібліографічного опису}

1.ISO/IEC 17025:2017. General requirements for the competence of testing and calibration laboratories.

2. Система управління НААУ Загальні вимоги до компетентності випробувальних та калібрувальних лабораторій (відповідно до ISO/IEC 17025:2017).

3. ДСТУ EN ISO/IEC 17065:2014. Оцінка відповідності. Вимоги до органів з сертифікації продукції, процесів та послуг.(ЕN ISO/IEC 17065:2012, IDT). Чинний від 2016-01-01. Вид. офіц. Київ: Держспоживстандарт України, 2014. 101 с.

4. ДСТУ EN ISO/IEC 17043:2014. Оцінка відповідності. Загальні вимоги до перевірки кваліфікації лабораторій.(EN ISO/IEC 17043:2010, IDT). Чинний від 2016-01-01. Вид. офіц. Київ: Держспоживстандарт України, 2014. 89 с.

5. ДСТУ ISO/IEC 17025:2006. Загальні вимоги до компетентності випробувальних та калібрувальних лабораторій.(ISO/IEC 17025:2005, IDT). Чинний від 2007-01-07. Вид. офіц. Київ: Держспоживстандарт України, 2006. 72 с.

6. ДСТУ 3412-96. Державна система сертифікації УкрСЕПРО. Вимоги до випробувальних лабораторій та порядок їх акредитації.Чинний від 2003-03-01. Вид. офіц. Київ: Держспоживстандарт України, 2003. 65 с.

7. Про технічні регламенти та оцінку відповідності:Закон України від 15 січня 2015 р. № 124-VIII. Вiдомості Верховної Ради. 2015. № 14.C.96.

8. ISO Guide 80.Guidanceforthein- house preparation of quality control materials

9. ISO/IEC 25010:2011. Systems and software engineering - Systems and software Quality Requirements and Evaluation - Systemand software quality models.

10. ISO/IEC 17021:2011.Conformityassessment-Requirements for bodies providing audit and certification of management systems.

11. ISO/IEC Guide 68:2002. Arrangements for the recognition and acceptance of conformity assessment results.

12.Випробування продукції. Види випробувань. URL: https://helpiks.org/2-3822.html.

13. ISO 9000: 2000. Quality Management Systems. Fundamentals And Vocabulary.

14. Мельниченко О. А., Хорошилов О. М., Малецька О. Є. (2019). Аналіз вимог до обладнання та методик за ISO/IEC 17025:2017.

15.Выбор испытательной лаборатории. URL: https://ukrcert.com/script/index_lab.php.

16.Бизнес-Гид. URL: https://dgcsms.biz-gid.ru/products/unit?pid=197345.

17. Кузьмич Л. В.Сучасні тенденції створення приладових систем вимірювання механічних величин. Збірник наукових праць Одеської державної академії технічного регулювання та якості. 2016, 1 (8), 95-99.

18. Чинков В.М., Ярохіна О.О. (2013). Основні тенденції розвитку вимірювальних функціональних генераторів сигналів.3бірник наукових праџь Харківського університету Повітряних Сил., 1(34),170-172.

19. Черніков М.М., Куваєва В.І., Болтьонков В.О. (2018). Система розподіленої колективної експертизи з захистом від фальсифікацій. Комп'ютерно-інтегровані технології: освіта, наука, виробництво, 30-31, 276-280.

\section{References}

1.ISO/IEC 17025:2017. General requirements for the competence of testing and calibration laboratories.

2. NAAU management system General requirements for the competence of testing and calibration laboratories (according to ISO / IEC 17025: 2017).

3. DSTU EN ISO / IEC 17065: 2014. Conformity assessment. Requirements for certification bodies for products, processes and services (EN ISO / IEC 17065: 2012, IDT). Valid from 2016-01-01. Kind. ofits. Kyiv: Derzhspozhyvstandart Ukrainy, 2014. 101 p.

4. DSTU EN ISO / IEC 17043: 2014. Conformity assessment. General requirements for laboratory qualification testing (EN ISO / IEC 17043: 2010, IDT). Valid from 2016-01-01. Kind. ofits. Kyiv: Derzhspozhyvstandart Ukrainy, 2014. 89 p.

5. DSTU ISO / IES 17025: 2006. General requirements for the competence of testing and calibration laboratories (ISO / IEC 17025 : 2005, IDT). Valid from 2007-01-07. Kind. ofits. Kyiv: Derzhspozhyvstandart Ukrainy, 2006. 72 p.

6. DSTU 3412-96. State certification system UkrSEPRO. Requirements for testing laboratories and the procedure for their accreditation. Valid from 2003-03-01. Kind. ofits. Kyiv: Derzhspozhyvstandart Ukrainy, 2003. 65 p.

7. On technical regulations and conformity assessment: Law of Ukraine of January 15, 2015 № 124-VIII. Information of the Verkhovna Rada. 2015. № 14.C.96.

8. ISO Guide 80 .Guidanceforthein- house preparation of quality control materials

9. ISO/IEC 25010:2011. Systems and software engineering - Systems and software Quality Requirements and Evaluation - Systemand software quality models.

10. ISO/IEC 17021:2011.Conformityassessment-Requirements for bodies providing audit and certification of management systems.

11. ISO/IEC Guide 68:2002. Arrangements for the recognition and acceptance of conformity assessment results.

12. Product testing. Types of tests. URL: https://helpiks.org/2-3822.html.

13. ISO 9000: 2000. Quality Management Systems. Fundamentals And Vocabulary.

14. Melnichenko, O. A., Khoroshilov, O. M., Maletska,O. C. (2019). Analysis of vimog to the possession of those methods for ISO / IEC 17025: 2017

15. Choosing a testing laboratory. URL: https://ukrcert.com/script/index_lab.php.

16. Business Guide. URL: https://dgcsms.biz-gid.ru/products/unit?pid=197345.

17. Kuzmich, L. V. (2016). Current tendencies in the development of the near-ladder systems in the measurement of mechanical values. Collection of Science Practitioners of the Odessa State Academy of Technical Regulation and Yakosti, 1 (8), 95-99.

18. Chinkov, V.M., Yarokhina, O.O. (2013). Basic tendencies in the development of dynamic functional signal generators. Library of Science Practitioners of Kharkiv University of Powers, 1 (34), 170-172.

19. Chernikov, M.M., Kuvaeva, V.I., Boltyonkov,V.O. (2018). The system of distribution of collective expertise with a variety of falsifications. Computer-integrated technologies: education, science, virobnitsvo, 30-31, 276-280. 